Jurnal Ilmiah Kebidanan (Scientific Journal of Midwifery), Vol 6, No. 1 Tahun 2020

\title{
FAKTOR RISIKO KEJADIAN BERAT BADAN LAHIR RENDAH PADA MASYARAKAT PENAMBANG BATU DI WILAYAH MORAMO UTARA
}

\section{Risk Factors For Low Birth Weight In The Community Of Stone Miners In The North Moramo Region}

\author{
Liyusri $^{1}$, Tasnim ${ }^{2}$, Sultan Akbar Toruntju ${ }^{3}$ \\ ${ }^{1,2}$ STIKES Mandala Waluya Kendari \\ ${ }^{3}$ Polilteknik Kesehatan Kendari \\ Email : liyusri1992@gmail.com
}

\section{Riwayat Artikel}

Diajukan: Agustus 2019

Diterima: Maret 2020

\section{Penulis Korespondensi:}

- Liyusri

- STIKES Mandala Waluya

Kendari

- liyusri1992@gmail.com

\section{Kata Kunci:}

Umur, Paritas, Pola Makan, Riwayat Penyakit, BBLR

\section{ABSTRAK}

Kasus BBLR berisiko mengalami peningkatan mortalitas dan morbiditas, perlu dilakukan identifikasi faktor kejadian BBLR. Studi ini menganalisis faktor risiko untuk kejadian BBLR. Penelitian ini adalah penelitian yang terdiri dari dua kelompok case dan control yang dirancang dengan desain studi kasus. Populasi adalah ibu yang telah dikumpulkan dengan sampel 54 responden dibagi menjadi dua kelompok kasus dan kelompok kontrol. Pengambilan sampel dalam kelompok, penelitian dengan teknik pengambilan sampel acak sederhana dan pada kelompok kontrol mengambil sampel yang sesuai dengan kelompok umur sehingga memperoleh jumlah sampel yang sama antara kelompok kasus dan kelompok kontrol. Variabel yang diteliti adalah umur saat hamil, paritas, pola makan dan riwayat penyakit, analisis data menggunakan Odd Ratio dan regresi logistik multivariat $(\mathrm{a}=0,05)$. Faktor-faktor yang terkait dengan berat lahir rendah selama kehamilan adalah umur $(\mathrm{p}=0,013)$, paritas $(\mathrm{p}=$ $0,002)$,pola makan $(p=0,001)$ dan riwayat penyakit $(p=0,000)$. Hasil analisis regresi logistik menunjukkan umur selama kehamilan merupakan faktor risiko BBLR dan faktor paling berpengaruh $(\mathrm{OR}=$ 13.311; 95\% CI 1.753-101.080). umur (<20 dan > 35 tahun) berisiko 13 kali melahirkan bayi dengan kelahiran rendah dibandingkan ibu berusia 20-35 tahun. Diharapkan ibu menghindari risiko kehamilan pada usia (<20 tahun dan $>35$ tahun) dan dilakukannya sosialisasi tenaga kesehatan terkait tentang kehamilan berisiko untuk menurunkanrisiko BBLR.

Kata kunci: Umur; paritas;pola makan; Riwayat penyakit; BBLR. 


\begin{abstract}
Cases of low birth weight ( $L B W)$ are at risk of increasing mortality and morbidity, it is necessary to identify identification of $L B W$ incidence factors. This study analyzed the risk factors for $L B W$ events. This research is a study consisting of two groups and case control designed with a case study design. The population is mothers who have been collected with a sample of 54 respondents divided into two case groups and a control group. Sampling in the study group with a simple random sampling technique and in the control group took samples that matched the age group so that they obtained the same number of samples between the case group and the control group. Variables published were age at pregnancy, parity, diet and disease history, analysis of data using Odd Ratio and multivariate logistic regression $(a=0.05)$.Factors associated with low birth weight during pregnancy were age $(p=0.013)$, parity $(p=0.002)$, diet $(p=0.001)$ and disease history $(p=0.000)$. The results of logistic regression analysis showed that the age during pregnancy was a risk factor for $L B W$ and the most influential factor $(O R=13,311 ; 95 \%$ CI 1,753-101,080). age (<20 and $>35$ years) has a risk of 13 times giving birth to babies with low births compared to mothers aged 20-35 years. It is expected that the mother avoids the risk of pregnancy at age ( $<20$ years and $>35$ years) and the dissemination of related health workers about risky pregnancies to reduce the risk of $L B W$.
\end{abstract}

Keywords: Age; parity;diet; history of disease; $L B W$.

\section{PENDAHULUAN}

Berat Badan Lahir Rendah (BBLR) merupakan bayi lahir yang di timbang dalam satu (1) jam dengan berat badan kurang dari 2500 gram tanpa memperhitungkan usia kehamilan. Prematur, Intrauterine Growth Retardation (IUGR) dan Serotinus adalah pembagian jenis BBLR (IDAI., 2004).

Penyebab utama, terjadinya kematian bayi antara lain adalah BBLR, asfiksia dan infeksi dengan hasil frekwensi kejadiannya sekitar 29\%. Data (WHO, 2016)Indonesia berada pada urutan kelima sebagai negara jumlah bayi BBLR terbanyak diduniayang diidenfitikasi sebagai penyumbang terbesar angka kematian bayi. Asia Selatan memiliki kejadian tertinggi, dengan 28 per 100 ribu kelahiran bayi dengan BBLR, Sedangkan Asia Timur/Pasifik memiliki tingkat terendah, yaitu 6 per 100 kelahiran. Sementara kasus tertinggi berada di kawasan Asia Selatan seperti India dan Bangladesh.

Balitbangkes and Kemenkes RI, (2013) dan (Pramono \& Paramita, 2015) berpendapat bahwa angka nasional Indonesia mengenai persentase BBLR tahun 2013 adalah 102 per 100 ribu kelahiran artinya, 1 dari 10 bayi di Indonesia yang terlahir dengan BBLR. Dengan kondsisi seperti ini maka BBLR menjadi penyumbang permasalahan Balita pada masa yang akan datang jika tidak mendapat penanganan secara baik dan benar pada masa BBLR (Banudi, 2013).

Sementara, angka BBLR di Sulawesi Tenggara Tahun 2017 yaitu 32 per 1000 kelahiran, kejadian tertinggi berada di sulawesi tengah yaitu 89 per 1000 kelahiran dan yang terendah berada di jambi yaitu 26 per 1000 kelahiran (Sultra, 2017). Namun tahun 2018 terjadi peningkatan di sulawesi tenggara yaitu sekitar 58 per 1000 kelahiran(Riskesdas, 2018). Sedangkan, data kejadian BBLR di Konawe Selatan Tahun 2017 yaitu 31 per 1000 kelahiran angka ini masih tinggi jika dibandingkan dengan Kabupaten Konawe yaitu sekitar 18 per 1000 kelahiran dan Konawe Utara yaitu sekitar 17 per seribu kelahiran(Sultra, 2017). Sedangkan untuk kejadian BBLR tertinggi berada di wakatobi yaitu 37 per 1000 kelahiran dan terendah berada di muna barat (BPS. Sultra, 2017).

Menurut data Profil Puskesmas Lalowaru(2017), angka kejadian BBLR yaitu4 bayi BBLR dari 206 jumlah bayi 
lahir tahun 2016 dan 19 Bayi BBLR dari jumlah 202 bayi lahir tahun 2017. Angka ini merupakan kasus yang cukup tinggi, bila dibandingkan dengan data BBLR di Puskesmas Moramo (2017) yaitu 17 dan data BBLR di Puskesmas Lameuru yaitu 7 bayi BBLR. Sedangkan data kejadian BBLR di Wilayah Moramo Utara adalah 36 bayi BBLR dari jumlah 261 bayi lahir tahun 2018 (Lalowaru dan Moramo, 2018).

Masih tingginya kejadian BBLR di wilayah moramo Utara ini dimungkinkan adanya dampak kerusakan lingkungan dan adanya aktivitas pertambangan batu yang letaknya berada di lingkungan pemukiman tempat tinggal masyarakat sebagaimana diketahui bahwa kesehatan lingkungan tempat tinggal adalah keseimbangan ekologi yang selalu ada antara manusia dan lingkungan tempat tinggal sehingga dapat menjamin suatu keadaan sehat pada manusia (Jayadipraja, Daud, \& Assegaf, 2016; WHO, 2014) dan adanya aktivitas pertambangan tersebut menyebabkan pencemaran lingkungan sebagaimana dalam Undang-undang RI No. 23 Tahun 1997 tentang pengelolaan lingkungan hidup Pasal 1 ayat (12) menyebutkan: "Pencemaran lingkungan adalah masuknya atau dimasukkannya makhluk hidup zat energi dan/atau komponen lain kedalam lingkungan hidup oleh kegiatan manusia sehingga kualitasnya turun sampai tingkat tertentu yang menyebabkan lingkungan hidup tidak dapat berfungsi sesuai dengan bentuknya (Sumantri Arif, 2017).Tujuan umum penelitian ini adalah untuk menganalisis faktor risiko kejadian BBLR di Wilayah Moramo Utara.

\section{METODE}

Penelitian ini menggunakan Design Case control study yang merupakan penelitian observasional dibagi menjadi dua kelompok, yaitu kelompok kasus dan kelompok kontrol yang kemudian meneliti faktor risiko secara retrospektif. Penelitian ini berlangsung pada Bulan Mei - Juli 2019. Populasi kasus dalam penelitian ini adalah seluruh bayi BBLR yang berjumlah 36 orang di Wilayah Moramo Utara sedangkan populasi kelompok kontrol berjumlah 261 orang.Tehnik Pengambilan sampel pada kelompok kasus penelitian ini dilakukan dengan tehnik simpel random sampling dan pada kelompok kontrol tehnik pengambilan sampel matching kelompok umur sehingga didapatkan jumlah sampel yang sama antara kelompok kasus 27 responden dan kelompok kontrol 27 responden. Variabel dependen : berat badan lahir rendah (BBLR) dan Independen : Umur, Paritas, pola makan dan Riwayat Penyakit.

\section{HASIL DAN PEMBAHASAN}

Penelitian ini bertujuan untuk mencari hubungan variabel dependen dengan variabel independen pada kasus terhadap kontrol.Hubungan umur ibu saat hamil dengan berat badan lahir rendah (BBLR).

Tabel 1. Hubungan Umur Ibu Hamil dengan Kejadian Berat Badan Lahir Rendah BBLR pada Masyarakat Penambang Batu di Wilayah Moramo Utara

\begin{tabular}{|c|l|c|c|c|c|c|}
\hline \multirow{2}{*}{ Umur } & \multicolumn{2}{|c|}{ Kasus } & \multicolumn{2}{|c|}{ Kontrol } & $\begin{array}{c}\text { Nilai } \\
p\end{array}$ & $\begin{array}{c}\text { OR } \\
\text { (CI 95\%) }\end{array}$ \\
\cline { 2 - 5 } & $\mathrm{n}$ & $\%$ & $\mathrm{n}$ & $\%$ & & \\
\hline Berisiko & 16 & 59.3 & 7 & 25.9 & & $\begin{array}{r}4.156 \\
(1.312- \\
13.169)\end{array}$ \\
\hline $\begin{array}{c}\text { Tidak } \\
\text { berisiko }\end{array}$ & 11 & 40.7 & 20 & 74.1 & & \\
\hline Total & 27 & 50.0 & 27 & 50.0 & & \\
\hline
\end{tabular}

Sumber : Data Primer 2019

Tabel 1, menunjukkan bahwap value pada hasil uji pearsonchi square adalah sebesar 0,013. Karena nilai $p$ value $0,013<0,05$ atau nilai pearsonchi square hitung6.135> 3.841 chi square tabel, 
disimpulkan bahwa ada hubungan umur responden saat melahirkan terhadap kejadian BBLR. Parameter kekuatan hubungan yang digunakan adalah OR yaitu sebesar 4.156 dengan CI 95\% 1.312 13.169, artinya umur $<20$ dan $>35$ berisiko mempunyai kemungkinan 4 kali untuk melahirkan bayi BBLR dibandingkan dengan responden yang umurnya $20-35$ tahun.

Hasil tersebut di atas sejalan dengan hasil penelitian (Kusparlina, 2016), menuliskan bahwa lebih banyak ibu melahirkan bayi BBLR pada umur yang tidak aman. Hal ini sama dengan hasil penelitian (Indrasari, 2016), bahwa umur mempunyai pengaruh terhadap kejadian BBLR yaitu usia ibu beresiko $(\mathrm{p}=0,014)$. (Evasari, 2016), dalam penelitiannya penuliskan bahwanya adanya hubungan yang bermakna umur ibu dengan kejadian BBLR. Namun ada juga jurnal penelitian yang mendapatkan hasil penelitian yang berbeda yaitu hasil penelitian (Kristiana \& Juliansyah, 2017) yang menuliskan bahwa umur tidak berhubungan dengan kejadian BBLR.

Tabel 2. Hubungan paritas dengan berat badan lahir rendah (BBLR) pada Masyarakat Penambang Batu di Wilayah Moramo Utara

\begin{tabular}{|c|c|c|c|c|c|c|}
\hline \multirow{2}{*}{ Paritas } & \multicolumn{2}{|c|}{ Kasus } & \multicolumn{2}{|c|}{ Kontrol } & $\begin{array}{c}\text { Nilai } \\
p\end{array}$ & $\begin{array}{c}\text { OR } \\
\text { (CI 95\%) }\end{array}$ \\
\hline & $\mathrm{n}$ & $\%$ & $\mathrm{n}$ & $\%$ & \multirow{4}{*}{0.002} & \multirow{4}{*}{$\begin{array}{c}5.950 \\
(1.797- \\
19.699)\end{array}$} \\
\hline Kurang & 17 & 73.9 & 6 & 26.1 & & \\
\hline Baik & 10 & 32.3 & 21 & 67.7 & & \\
\hline Total & 27 & 50.0 & 27 & 50.0 & & \\
\hline
\end{tabular}

Sumber : Data Primer 2019

Hasil penelitian nilai $p$ value $0.002<0.05$ atau nilai pearsonchi square hitung9.164> 3.841 chi square tabel disimpulkan bahwa ada hubungan paritas dengan kejadian BBLR Menurut (Manuaba. 2010) seseorang yang hamil 2-3 tergolong masih dalam kondisi aman dan lebih dari 3 dikategorikan dalam kondisi tidak aman. Hal ini disebabkan bayi dengan berat lahir rendah paling banyak terjadi pada paritas diatas lima karena sudah mengalami kemunduran fungsi pada alatalat reproduksi. Paritas yang tinggi berdampak timbulnya masalah kesehatan yang akan mempengaruhi kondisi ibu maupun kondisi janin. Salah satu dampak kesehatan yang mungkin timbul adalah kejadian BBLR (Berat Bayi Lahir Rendah). Hal ini sama dengan penelitian (Kurniasari, 2018) ada hubungan yang bermakna antara Paritas dengan Kejadian BBLR di RSIA Annisa Kota Jambi Tahun 2017. Nilai OR $=2,015 \quad(95 \% \mathrm{CI}=3,500-1,160)$, menunjukkan bahwa ibu yang mengalami paritas mempunyai risiko 2,015 kali lebih besar mengalami kejadian BBLR dari pada ibu yang tidak memiliki paritas. Penelitian yang dilakukan oleh (Meihartati, 2016) menyatakan bahwa, multiparitas merupakan salah satu faktor resiko terhada terjadinya BBLR dengan kata lain paritas mempunyai hubungan yang bermakna terhadap kejadian BBLR.

Tabel 3. Hubungan pola makan terhadap berat badan lahir rendah (BBLR) pada Masyarakat Penambang Batu di Wilayah Moramo Utara

\begin{tabular}{|c|c|c|c|c|c|c|}
\hline \multirow{2}{*}{$\begin{array}{c}\text { Pola } \\
\text { makan }\end{array}$} & \multicolumn{2}{|c|}{ Kasus } & \multicolumn{2}{|c|}{ Kontrol } & $\begin{array}{c}\text { Nilai } \\
p\end{array}$ & $\begin{array}{c}\text { OR } \\
(\mathrm{CI} 95 \%)\end{array}$ \\
\cline { 2 - 5 } & $\mathrm{n}$ & $\%$ & $\mathrm{n}$ & $\%$ & & \\
\hline Berisiko & 19 & 70.4 & 7 & 25.9 & & $\begin{array}{c}6.786 \\
(2.058- \\
22.372)\end{array}$ \\
\hline $\begin{array}{c}\text { Tidak } \\
\text { Berisiko }\end{array}$ & 8 & 29.6 & 20 & 74.1 & & \\
\hline Total & 27 & 50.0 & 27 & 50.0 & & \\
\hline
\end{tabular}

Sumber : Data Primer 2019 
Hasil penelitian nilai $p$ value $0.001<$ 0.05 atau nilai pearsonchi square hitung10.681 > 3.841 chi square tabel disimpulkan bahwa ada hubungan pola makan dengan kejadian BBLR. Berdasarkan tinjuan teori pola makan adalah merupakan salah satu faktor penyebab terjadinya penyakit misal anemia sehingga dapat menyebabkan bayi BBLR hal ini sejalan dengan penelitian (Harti, Kusumastuty, \& Hariadi, 2016)Ada hubungan antara pola makan makanan pokok terhadap penambahan berat badan $(\mathrm{p}=0,003, \mathrm{r}=0,344)$, dan ada hubungan antara pola makan (pola makan makanan pokok dan lauk hewani) terhadap penambahan berat badan ibu hamil hal ini dapat mempengaruhi kecukupan gizi janin dalam kandungan.

Penelitian yang dilakukan oleh (US Widy, 2014) didapatkan hasil bahwa jenis makanan yang dikonsumsi sudah memenuhi sudah memenuhi kualitas dan kuantitasnya, sedangkan konsumsi protein dan lemak tidak memenuhi kebutuhan. Hasil penelitian yang dilakukan oleh (Leny Budhi H., 2016) didapatkan bahwa ada hubungan yang bermakna antara BBLR terhadap pertambahan berat badan ibu hamil ( $\mathrm{p}=0,024, \mathrm{r}=0,268)$. Hasil penelitian (Widyaningrum, 2017) menuliskan terdapat hubungan antara pola konsumsi makanan sumber vitamin A $(\mathrm{p}=0,034)$, pola konsumsi makanan sumber zat besi $(\mathrm{p}=0,036)$ dan konsumsi tablet besi $(\mathrm{p}=0,020)$ dengan kejadian BBLR. Sedangkan pola konsumsi makanan sumber karbohidrat $(\mathrm{p}=0,335)$, pola konsumsi makanan sumber protein $(\mathrm{p}=0,847)$, pola konsumsi makanan sumber lemak $(\mathrm{p}=0,441)$, pola konsumsi makanan sumber yodium $(\mathrm{p}=0,245)$, pola konsumsi makanan sumber asam folat $(\mathrm{p}=0,554)$ dan peningkatan berat badan pada ibu hamil $(\mathrm{p}=0,221)$ tidak berhubungan dengan kejadian BBLR dengan kata lain benar adanya hubungan pola makan terhadap kejadian BBLR. Manutrisi pada anak dapat berasal dari ibu yang mempunyai pola makan yang buruk saat hamil dan tidak dilakukannya ASI ekslusif pada waktu bayi (Tasnim, 2018).

Tabel 4. Hubungan Riwayat penyakit denganberat badan lahir rendah (BBLR) pada Masyarakat Penambang Batu di Wilayah Moramo Utara

\begin{tabular}{|c|c|c|c|c|c|c|}
\hline \multirow{2}{*}{$\begin{array}{c}\text { Riwayat } \\
\text { penyakit }\end{array}$} & \multicolumn{2}{|c|}{ Kasus } & \multicolumn{2}{|c|}{ kontrol } & \multicolumn{1}{|c|}{$\begin{array}{c}\text { Nilai } \\
p\end{array}$} & $\begin{array}{c}\text { OR } \\
\text { (CI 95\%) }\end{array}$ \\
\cline { 2 - 5 } & $\mathrm{n}$ & $\%$ & $\mathrm{n}$ & $\%$ & & \\
\hline Berisiko & 19 & 70.4 & 5 & 18.5 & & $\begin{array}{c}10.450 \\
(2.920- \\
37.392)\end{array}$ \\
\hline $\begin{array}{c}\text { Tidak } \\
\text { berisiko }\end{array}$ & 8 & 29.6 & 22 & 81.5 & 0.000 & \\
\hline Total & 27 & 50.0 & 27 & 50.0 & & \\
\hline
\end{tabular}

Sumber : Data Primer 2019

Hasil penelitian peneliti, nilai $p$ value $0.000<0.05$ atau nilai pearsonchi square hitung $10.450>3.841$ chi square tabel disimpulkan bahwa ada hubungan riwayat penyakit terhadap kejadian BBLR. Penyakit yang berhubungan langsung dengan kehamilan misalnya perdarahan antepartum, trauma fisik dan psikologis, anemia, toksemia gravidarum, dan nefritis akut. Kejadian infeksi pada masa kehamilan dapat berhubungan secara langsung maupun tidak langsung dengan kejadian BBLR, penyakit-penyakit infeksi pada kehamilan seperti penyakit malaria, toksoplasma, plasmodium dan infeksi virus. Infeksi virus yang terjadi saat hamil dapat menghambat pertumbuhan janin bahkan dapat menyebabkan kematian janin seperti pada infeksi virus rubella dan cytomegalo virus. Virus-virus tersebut dapat menyerang selama kehamilan sehingga dapat mengeluarkan toksin yang dapat mengurangi suplai darah ke janin dan 
dapat mengganngu pertumbuhan dan perkembangan janin selama kehamilan. Salah satu penyebab kejadian BBLR adalah infeksi pada saluran kemih dimana hal ini ini dapat menyebabkan infeksi pada air ketuban dan plasenta sehingga dapat mengganggu suplai makanan ke janin. Beberapa penyakit infeksi penyakit non infeksi juga dapat menjadi faktor resiko penyebab kejadian BBLR seperti penyakit ginjal kronis, hipertensi, dan diabetes melitus(Banudi, 2013; Saragih, 2017).

Hal ini sejalan dengan penelitian (Haryanti, Pangestuti, \& Kartini, 2019)Ibu yang mengalami penyakit anemia proporsi pada kelompok kasus lebih banyak yaitu sebesar 70\%. Hasil uji chi square didapatkan bahwa anemia pada ibu saat hamil sebagai faktor risiko kejadian BBLR $(p=0,001)$, sedangkan nilai $O R$ membuktikan bahwa bayi yang mengalami BBLR yang disebabkan oleh anemia adalah 9 kali lebih beresiko BBLR dibandingkan ibu yang tidak mengalami anemia. Hasil penelitian (Mallisa \& Towidjojo, 2014) yang menggunakan uji Fisher'sExact Test Chi-square dengan $p=0,003(p<0,05)$ dan kekuatan hubungan yanglemah $(0,215)$ yang berarti terdapat hubungan yang bermakna secara statsitik antara preeklampsia dengan kejadian BBLR. Pada penelitian ini juga didapatkan preeklampsia merupakan faktor risiko lebih besar yang menyebabkan BBLR dengan $\mathrm{OR}=2.48$. Sehingga hasil penelitiannya didapatkan bahwa ada hubungan yang bermakna secara statistik antara preeklampsia dengan kejadian BBLR di RSUD Undata Palu tahun 2011-2012.

Tabel 5. Model Faktor risiko kejadian BBLR pada Masyarakat Penambang Batu di Wilayah Moramo Utara

\begin{tabular}{llll}
\hline No & Variabel & Sig & $\operatorname{Exp~(B)~}$ \\
\hline
\end{tabular}

\begin{tabular}{lccc}
\hline 1 & Umur & 0,012 & 13.311 \\
2 & Paritas & 0,011 & 12.702 \\
3 & Pola Makan & 0,012 & 11.387 \\
3 & RiwayatPeyakit & 0,046 & 4.953 \\
\hline
\end{tabular}

Sumber : Data Primer 2019

Berdasarkan tabel di atas menunjukan bahwa variabel Umur saat hamil, paritas, pola makan dan riwayat penyakit adalah merupakan faktor risiko kejadian BBLR. Variabel paling berpengaruh adalah variabel Umur saat hamil dilihat dari nilai OR/Exp $(\mathrm{B})=13.311$ dan terkecil adalah variabel riwayat penyakit dengan nilai $\mathrm{OR} / \operatorname{Exp}(\mathrm{B})=4.953$.

\section{KESIMPULAN}

Dari pemaparan hasil dan pembahasan akhirnya dapat disimpulkan bahwa dari ketiga variabel bebas yaitu umur ibu saat hamil, paritas, pola makan dan riwayat kesehatan merupakan faktor risiko terhadap variabel terikat yaitu kejadian berat badan lahir rendah (BBLR).

\section{DAFTAR PUSTAKA}

BANUDI, L. 2013. Gizi kesehatan reproduksi. Jakarta: EGC.

BPS. SULTRA 2017. Badan Pusat Statistik Provinsi Sulawesi Tenggara. In: STATISTIK, B. P. (ed.). Kendari: BPS Provinsi Sulawesi Tenggara.

EVASARI, E. 2016. Hubungan Umur, Paritas dan Status Gizi Ibu dengan Kejadian BBLR. Jurnal Obstretika Scienta, 4.

HARTI, L. B., KUSUMASTUTY, I. \& HARIADI, I. 2016. Hubungan Status Gizi dan Pola Makan terhadap Penambahan Berat Badan Ibu Hamil (Correlation between Nutritional Status and Dietary Pattern on Pregnant Mother's Weight Gain). Indonesian Journal of Human Nutrition, 3, 54-62. 
HARYANTI, S. Y., PANGESTUTI, D. R. \& KARTINI, A. 2019. ANEMIA DAN KEK PADA IBU HAMIL SEBAGAI FAKTOR RISIKO KEJADIAN BAYI BERAT LAHIR RENDAH (BBLR)(Studi di Wilayah Kerja Puskesmas Juwana Kabupaten Pati). Jurnal Kesehatan Masyarakat (e-Journal), 7, 322329.

IDAI. 2004. Bayi Berat Lahir RendahStandar Pelayanan Medis Kesehatan Anak. Edisi I, Jakarta: IDAI.

INDRASARI, N. 2016. Faktor Resiko Pada Kejadian Berat Badan Lahir Rendah (BBLR). Jurnal Ilmiah Keperawatan Sai Betik, 8, 114-123.

JAYADIPRAJA, E. A., DAUD, A. \& ASSEGAF, A. H. 2016. Air Pollution and Lung Capacity of People Living around the Cement Industry. Public Health of Indonesia, 2, 76-83.

KRISTIANA, N. \& JULIANSYAH, E. 2017. Umur, Pendidikan, Pekerjaan Dan Pengetahuan Dengan Kejadian Berat Badan Lahir Rendah (BBLR). Jurnal Ilmiah Ilmu Kesehatan: Wawasan Kesehatan, 4, 7-14.

KURNIASARI, L. 2018. HUBUNGAN PARITAS, JARAK KELAHIRAN DAN RIWAYAT PREEKLAMPSIA DENGAN KEJADIAN BBLR DI RSIA ANNISA KOTA JAMBI TAHUN 2017. SCIENTIA JOURNAL, 7, 5357.

KUSPARLINA, E. P. 2016. Hubungan antara umur dan status gizi ibu berdasarkan ukuran lingkar lengan atas dengan jenis BBLR. Jurnal Penelitian Kesehatan" SUARA FORIKES"(Journal of Health Research" Forikes Voice"), 7.

LALOWARU DAN MORAMO 2018. Profil kesehatan Puskesmas
Lalowaru dan Moramo. In: DINKES (ed.). Moramo Utara: Lalowaru dan Moramo.

LENY BUDHI H., I. K., IRWAN H., 2016. Hubungan Status Gizi dan Pola Makan terhadap Penambahan Berat

Badan Ibu Hamil Indonesian Journal of Human Nutrition, 3 no.1, 54-62.

MALLISA, B. \& TOWIDJOJO, V. D. 2014. Hubungan antara Preeklampsia dengan Kejadian Bayi Berat Badan Lahir Rendah (BBLR) Di RSUD Undata Palu suatu Penelitian Case-Control. Medika Tadulako: Jurnal Ilmiah Kedokteran Fakultas Kedokteran dan Ilmu Kesehatan, 1, 1-7.

MEIHARTATI, T. 2016. Faktor Ibu yang Berhubungan dengan Kejadian Bayi Berat Lahir Rendah di RSUD Andi Abdurrahman Noor Tanah Bumbu 2015. Jurnal Delima Azhar, 2, 7177.

PRAMONO, M. S. \& PARAMITA, A. 2015. Pola Kejadian Dan Determinanbayi Dengan Berat Badan Lahir Rendah (Bblr) Di Indonesia Tahun 2013 (Pattern of Occurrence and Determinants of Baby with Low Birth Weight in Indonesia 2013). Buletin Penelitian Sistem Kesehatan, 18.

RISKESDAS 2018. Hasil Utama Riset Kesehatan dasar In: KEMENTERIAN KESEHATAN, R. (ed.). Sulawesi Tenggara: Riskesdar.

SARAGIH, I. D. 2017. GAMBARAN BERAT LAHIR RENDAH BERDASARKAN KUALITAS PELAYANAN ANTENATAL CARE DI INDONESIA TAHUN 2012 (ANALISIS LANJUT SKDI 2012). JUMANTIK (Jurnal Ilmiah Penelitian Kesehatan), 2, 61-77.

SULTRA 2017. Profil Kesehatan, Sulawesi Tenggara. In: TENGGARA, K. P. 
S. (ed.). Kendari: Dinas Kesehatan Provinsi Sulawesi Tenggara.

SUMANTRI ARIF 2017. Kesehatan Lingkungan Depok, KENCANA.

TASNIM, T. 2018. Determinants of Malnutrition in Children Under Five Years in Developing Countries: A Systematic Review. Indian Journal of Public Health Research \& Development, 9.

US WIDY 2014. Analisa pola makan ibu hamil dengan kondisi kurang energi kronik (kek) di kecamatan bobotsari, kabupaten purbalingga [skripsi]. Yogyakarta: Universitas Negeri Yogyakarta.
WHO 2014. Comprehensive Implementation Plan on Maternal, Infant and Young Child Nutrition. In: ORGANIZATION, W. H. (ed.). Geneva: WHO.

WHO 2016. Maternal Mortality. In: ORGANIZATION, W. H. (ed.). . Geneva: WHO.

WIDYANINGRUM, A. F. 2017. HUBUNGAN POLA KONSUMSI MAKAN DAN PENINGKATAN BERAT BADAN IBU HAMIL DENGAN KEJADIAN BERAT BAYI LAHIR RENDAH (Studi di Wilayah Kerja Puskesmas Gading Surabaya). UNIVERSITAS ERLANGGA. 